\title{
WPEYW PROCYKLICZNOŚCI NA SPRAWOWANIE NADZORU MAKROOSTROŻNOŚCIOWEGO
}

\section{WPROWADZENIE}

Procykliczność stanowi czasowy wymiar ryzyka systemowego i cechuje się procesem narastania w okresie dobrej koniunktury i materializacja w okresie recesji. W literaturze najczęściej podkreśla się, że jest to mechanizm, przez który fazy cyklu finansowego i koniunkturalnego nachodzą na siebie i wzajemnie wzmacniaja swoje wahania ${ }^{1}$, a czego efektem jest narastanie i materializowanie się nierównowag makrofinansowych, w tym baniek spekulacyjnych, co prowadzi do zaburzenia stabilności finansowej i kryzysu. O ile zasadne jest przeciwdziałanie nadmiernym wahaniom cyklu finansowego, o tyle nie jest możliwe jego pełne wyeliminowanie, gdyż jest on immanentną cechą gospodarki rynkowej. Źródła czynników procyklicznych mają zróżnicowany charakter, a za najważniejsze z nich można uznać politykę kredytową banków, na co wpływ mają również rozwiązanie przyjęte w zakresie systemu regulacji (np. wymogi kapitałowe, oceny agencji ratingowych, metoda wyceny i czynniki behawioralne). Mnogość i skomplikowana natura źródeł czynników procyklicznych implikuje zróżnicowane sposoby, za pomocą których się im przeciwdziała.

Artykuł ma na celu analizę wpływu czynników procyklicznych na sposób sprawowania nadzoru makroostrożnościowego. Cel artykułu określa postawioną tezę - natura procykliczności determinuje sposób prowadzenia nadzoru makroostrożnościowego. Osiągnięcie celu umożliwia sformułowanie praktycznych wskazówek dla nadzoru makroostrożnościowego, jak skutecznie zmniejszać wpływ procykliczności na system finansowy. Metody badawcze obejmuja analizę literatury i badań obcych oraz metodę dedukcyjna. Artykuł stanowi kontynuację badań autora nad istotą stabilności finansowej ${ }^{2}$.

* Artykuł wyraża wyłącznie poglądy autora i nie powinien być interpretowany jako stanowisko instytucji, w której jest zatrudniony. Artykuł jest oparty na części badania dla młodych naukowców i uczestników studiów doktoranckich na 2013 r. (KZIF/BMN/34/L3) pt.: „Ryzyko systemowe i jego wymiar czasowy - źródła oraz metody zapobiegania”, przeprowadzonego pod kierownictwem autora w Instytucie Finansów w Kolegium Zarządzania i Finansów SGH.

${ }^{1}$ Por. P. P. Athanasoglou, I. Daniilidis, Procyclicality in the Banking Industry: Causes, Consequences and Response, Working Paper 139, Bank of Greece 2011, s. 7-8.

${ }^{2}$ P. Smaga, Istota stabilności finansowej, Studia i Prace Kolegium Zarządzania i Finansów, Zeszyt Naukowy 124, Szkoła Główna Handlowa w Warszawie, Warszawa 2013, s. 118-119. 
$\mathrm{Na}$ początku artykułu zostanie przedstawiona idea paradoksu niestabilności finansowej, któremu często ulegaja podmioty rynkowe oceniające kondycję systemu finansowego. W kolejnych częściach kolejno analizowane będa dylematy, jakie dla sprawowania nadzoru makroostrożnościowego i używania antycyklicznych narzędzi niesie ze sobą natura procykliczności. Wnioski z analizy na końcu artykułu służą sformułowaniu wspomnianych praktycznych rekomendacji.

\section{PARADOKS NIESTABILNOŚCI - STABILNOŚĆ BIEŻĄCA I PRZYSZLA}

Próbę ograniczania procykliczności zasadnie jest rozpoczać od ustalenia, na który z czynników procyklicznych dane narzędzie ma oddziaływać, w jakim horyzoncie czasowym i jakie będą potencjalnie skutki uboczne. Aby ograniczać procykliczność, należy przyjąć dłuższy horyzont analizy, uwzględniający przyszłą niestabilność, tj. akumulowanie czynników strukturalnych sprzyjających materializacji ryzyka systemowego $\mathrm{w}$ przyszłości - takie podejście powinny też przyjąc instytucje sieci bezpieczeństwa finansowego, a w szczególności bank centralny.

Procykliczność wynika z faktu, że instytucje finansowe skupiają się na ocenie bieżącej ${ }^{3}$ stabilności finansowej i przez jej pryzmat oceniają swoją kondycję oraz podejmują decyzje biznesowe. Procykliczności może więc sprzyjać zjawisko „paradoksu niestabilności” ${ }^{4}$ - nie w pełni efektywne rynki finansowe większy nacisk kładą na ocenę krótkookresowej perspektywy sytuacji finansowej danych podmiotów i całej gospodarki, przez co wspierają nadmierny optymizm i pomijają zagrożenia wynikające z ryzyka systemowego, które się kumuluje, choć jego materializacja może nastapić później. Powoduje to, że istnieje rozdźwięk w ocenie dokonanej przez banki między percepcją ryzyka a jego obiektywną wartością zarówno w okresie ożywienia, jak i recesji. Banki reagują w bieżacej polityce kredytowej na materializację ryzyka podejmowanego w wyniku przeszłej polityki kredytowej. Taka konstrukcja sprzyja procykliczności i przyjmowaniu krótkookresowego horyzontu w polityce kredytowej banków.

\footnotetext{
${ }^{3}$ Na rozróżnienie bieżącej i przyszłej (nie)stabilności systemu finansowego wskazuje J. K. Solarz, Wyzwania stojace przed polskim systemem bankowym u progu XXI wieku, w: L. Oręziak, B. Pietrzak (red.), Bankowość na świecie $i$ w Polsce: stan obecny $i$ tendencje rozwojowe, Olympus Centrum Edukacji i Rozwoju Biznesu, Warszawa 2001, s. 290.

${ }^{4}$ Por. H. Hannoun, Towards a Global Financial Stability Framework, speech at 45th SEACEN Governors' Conference Siem Reap province, Cambodia 26-27 February 2010, s. 5. Wskaźniki określające ryzyko ulegaja poprawie w okresie dobrej koniunktury, ceny aktywów rosna, a spready odzwierciedlające ryzyko zwężają się aż do momentu zwrotnego. Może to sprawiać wrażenie, że ryzyko spada w okresie boomu, podczas gdy w rzeczywistości kumulują się nierównowagi. Por. C. Borio, W. White, Whither Monetary and Financial Stability? The Implications of Evolving Policy Regimes, BIS Working Papers no 147, February 2004, s. 5-24. Podobnie posługiwanie się definicją stabilności finansowej według wąskiego ujęcia (tj. brak kryzysu), podczas narastania bańki może również prowadzić do paradoksu niestabilności. Por. P. Smaga, op. cit., s. 109.
} 
W okresie ożywienia łagodzenie polityki kredytowej, wzrost konkurencji i niedoszacowanie ryzyka prowadzą do udzielania kredytów na inwestycje o NPV nawet bliskim zera, co zwiększa narażenie na przyszłą niestabilność. Również kredytobiorcy mają tendencję do nadmiernego optymizmu przy ocenie projektów inwestycyjnych, na które potrzebują finansowania. Kredyty udzielane w okresie ożywienia mogą zatem w największym stopniu przyczyniać się do wzrostu NPL w okresie recesji. Jednocześnie w okresie recesji, ze względu na wzrost awersji do ryzyka, nawet inwestycje z dodatnim NPV nie otrzymuja finansowania. W przypadku wystapienia zjawiska racjonowania kredytu awersja banków do ryzyka przejawia się znaczącym i nagłym obniżeniem akcji kredytowej, co jest w dużej mierze niezależne od stosowanych instrumentów polityki pieniężnej banku centralnego oraz od rynkowych stóp procentowych, a może też wynikać z rozwiązań regulacyjnych. Nawet pomimo istnienia popytu na kredyt i wystarczającej zdolności kredytowej potencjalnych kredytobiorców, banki ograniczają finansowanie lub go odmawiaja. Analizowane zależności przedstawia tabela 1.

\section{Tabela 1}

Bieżący i przyszły wymiar stabilności a procykliczność

\begin{tabular}{|c|c|c|c|}
\hline $\begin{array}{l}\text { Faza } \\
\text { cyklu }\end{array}$ & $\begin{array}{c}\text { Ocena stabilności } \\
\text { bieżącej }\end{array}$ & Procykliczne efekty & $\begin{array}{c}\text { Wpływ na } \\
\text { stabilność przyszłą }\end{array}$ \\
\hline Ożywienie & poprawa & $\begin{array}{l}\text { - } \text { wzrost apetytu na ryzyko i dźwigni } \\
\text { - nadmierny rozwój akcji kredytowej } \\
\text { - narastanie nierównowag }\end{array}$ & potencjalne pogorszenie \\
\hline Recesja & pogorszenie & $\begin{array}{ll}\text { - } & \text { spadek apetytu na ryzyko } \\
\text { - } & \text { nadmierny spadek akcji kredytowej } \\
\text { - } & \text { wzrost trudności w wypełnieniu } \\
& \text { wymogów kapitałowych } \\
\text { - } & \text { materializacja nierównowag }\end{array}$ & $\begin{array}{l}\text { wpływ } \\
\text { niejednoznaczny }\end{array}$ \\
\hline
\end{tabular}

Źródło: opracowanie własne.

Model Banku Czech ${ }^{5}$ (por. schemat 1) dobrze pozwala z perspektywy makroostrożnościowej przeanalizować przebieg i rozwój ryzyka systemowego w czasie (wymiar czasowy) przez pryzmat zmieniającego się poziomu dźwigni, czego przykładem jest właśnie procykliczność. Ze schematu można odczytać, że ryzyko systemowe narasta $\mathrm{w}$ okresie ożywienia, a materializuje się w okresie dekoniunktury. Ważne jest, aby nie ulegać paradoksowi niestabilności, gdyż w okresie boomu pozornie można oceniać system jako stabilny. Mowa tu o ocenie bieżącej stabilności, a ryzyko systemowe, rozumiane jako potencjał przyszłej niestabilności, jest kumulowane w systemie. Może być trudno zidentyfikować czynniki sprzyjające cyklicznemu narastaniu przyszłej niestabilności ${ }^{6}$,

${ }^{5}$ Por. J. Frait, Z. Komárková, Financial Stability, Systemic Risk and Macroprudential Policy, Czech National Bank / Financial Stability Report 2010/2011, CNB 2011, s. 99-102.

${ }_{6}$ Zdefiniowanie, a także ocena czynników wpływających na stabilność finansową nie są zadaniem łatwym i wymagają odpowiedniego zaangażowania podmiotów odpowiedzialnych za 
ponieważ w okresie boomu takie wskaźniki, jak NPL, PD i LGD, obniżają się świadczy to jednak tylko o bieżącej, a nie o przyszłej stabilności finansowej. Nie należy jednak zakładać, co może sugerować pobieżna analiza modelu, że ryzyko systemowe zawsze zmniejsza się w okresie recesji - może być wręcz odwrotnie, gdy osłabione szokiem (i wciąż przelewarowane) instytucje finansowe są bardziej podatne na efekt zarażania. Zadaniem sieci bezpieczeństwa finansowego jest więc identyfikacja czynników sprzyjających procyklicznej akumulacji ryzyka systemowego, oddziałujących na przyszłą stabilność finansowa, a w konsekwencji prewencja i zapobieganie narastaniu ryzyka systemowego. $\mathrm{Z}$ analizy modelu Banku Czech wynika, że równie istotne jest, by nie tylko oddziaływać w okresie narastania ryzyka, lecz ograniczać negatywne skutki jego materializacji w okresie dekoniunktury przez mniej restrykcyjna politykę nadzorcza.

\section{Schemat 1}

\section{Procykliczna akumulacja ryzyka systemowego}

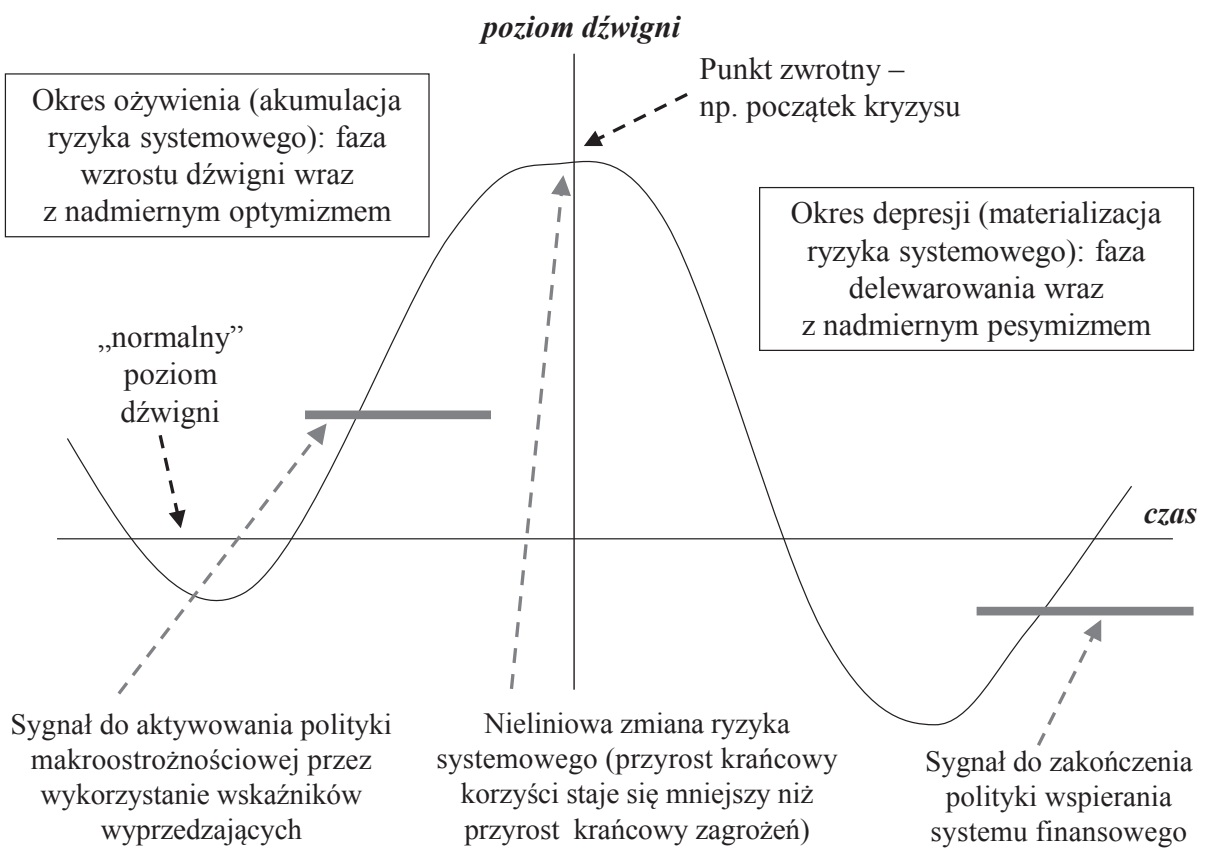

Źródło: opracowanie własne na podstawie J. Frait, Z. Komárková, Financial Stability, Systemic Risk and Macroprudential Policy, Czech National Bank, Financial Stability Report 2010/2011, CNB 2011, s. 99.

jej utrzymanie, odpowiednich instrumentów wspomagających jej utrzymanie bądź przywracanie, a także odpowiednich analiz i monitorowania zagrożeń, które moga mieć różne źródła. Por. M. Iwanicz-Drozdowska, Definicje i determinanty stabilności finansowej, Część Edukacyjna „Stabilność finansowa od a do z”, „Bank i Kredyt” 2011, nr 1, s. 15. 
Miary ryzyka z perspektywy mikro w okresie boomu wskazuja, że ryzyko obniża się, podczas gdy w niewystarczającym stopniu informują one o rosnącym ryzyku w wymiarze makro. Wykorzystanie więc zmiennych z rynku finansowego w procesie modelowania nierównowag makrofinansowych czy systemu finansowego może częściowo zaburzać trafność ich wskazań, ze względu na niską korelację między nimi w okresie ożywienia (a na tym opierały się wewnętrzne modele zarządzania ryzykiem w bankach przed kryzysem $)^{7}$, która okazała się wysoka w okresie niestabilności. Ich przydatność w identyfikacji ryzyka systemowego w wymiarze czasowym może być więc ograniczona. W niedostatecznym stopniu sygnalizują przyszłą niestabilność, skupiając się na ocenie bieżącej niestabilności. R. Maino et al. ${ }^{8}$ są zdania, że aktualnie używane wskaźniki stabilności finansowej najlepiej pełnią swoją funkcję w okresach przejściowych między fazami cyklu finansowego. Sposobem na częściowe zniwelowanie wspomnianej wady jest wspomniane przyjmowanie odpowiednio długiego horyzontu czasowego w danych wykorzystywanych do identyfikacji ryzyka systemowego.

Z tempem wzrostu PKB odwrotnie skorelowane są rezerwy tworzone przez banki i rosna zazwyczaj dopiero, gdy gospodarka znajduje się w recesji, co odzwierciedla ocenianie przez banki bieżącej (gdy ryzyko np. kredytowe się materializuje), a nie przyszłej stabilności. Takie podejście do naliczania rezerw przekłada się (ujemnie) na poziom wyniku finansowego banków i wzmaga procykliczność akcji kredytowej. W przypadku naliczania rezerw procyklicznie oddziałują też rozwiązania przyjęte w standardach rachunkowości, zgodnie z którymi odpowiednie rezerwy zawiązuje się dopiero w momencie, gdy ryzyko (np. kredytowe) jest bliskie materializacji lub już się zmaterializowało, a więc ex post, a nie ex ante. Banki moga mieć tendencję do opóźniania tworzenia rezerw do momentu materializacji ryzyka kredytowego oraz tworzenia ich w niewystarczającej wysokości w okresie ożywienia.

\section{ANTYCYKLICZNE PODEJŚCIE DO SPRAWOWANIA NADZORU MAKROOSTROŻNOŚCIOWEGO - DYLEMATY}

Analiza istoty procykliczności implikuje, że nadzór makroostrożnościowy powinien działać zarówno w okresie ożywienia, jak i dekoniunktury. Zasadne jest, by w okresie ożywienia dążył odpowiednio do ograniczenia narastania ryzyka systemowego przez stosowanie polityki antycyklicznej (zwiększanie wymogów kapitałowych, budowanie buforów kapitałowych) oraz w okresie recesji do obniżania wymaganych norm ostrożnościowych. Niezależnie od fazy cyklu powinien dążyć do wzmacniania odporności systemu finansowego na

\footnotetext{
${ }^{7}$ Szczególnie opieranie decyzji na modelach statystycznych, wykorzystujących dane historyczne sprzed okresu zaburzeń, może nie tylko spowodować powstanie błędnych informacji o aktualnym poziomie ryzyka, lecz także zwiększyć poziom ryzyka indywidualnego danego podmiotu, a nawet ryzyka systemowego. Por. J. Koleśnik, Bezpieczeństwo systemu bankowego. Teoria i praktyka, Difin, Warszawa 2011, s. 179.

${ }^{8}$ R. Maino et al., Macroprudential Policies for a Resource Rich Economy: The Case of Mongolia, IMF Working Paper WP/13/18, IMF 2013, s. 13.
} 
szoki (np. poprzez wprowadzenie dynamicznego systemu naliczania rezerw). Taka polityka sprzyjałaby ograniczeniu narastania nierównowag makrofinansowych i efektów zwrotnych między systemem finansowym a sferę realną. Jednak przyjęcie antycyklicznego nastawienia w polityce makroostrożnościowej stawia przed jej organem co najmniej dwa dylematy - w okresie ożywienia i w okresie recesji.

Po pierwsze, zaostrzanie polityki w okresie ożywienia może być postrzegane jako niepopularne działanie, ograniczajace zyski sektora finansowego, tzw. zabieranie wazy z ponczem (ang. taking away the punch bowl). Należy pamiętać, że to wzrost zysków sprzyja poprawie kondycji finansowej i potencjalnie poziomu kapitału (przy założeniu braku wypłaty dywidendy), a przez to wzrostowi odporności na szoki systemu finansowego, co jest pożądane przez nadzór makroostrożnościowy, choć może wystapić w niewystarczającym stopniu.

Po drugie, w okresie recesji przyjęcie ekspansywnej polityki makroostrożnościowej, np. zmniejszającej wymogi kapitałowe, może owszem oddziaływać $\mathrm{w}$ kierunku spadku tempa procesu delewarowania i ograniczania tempa akcji kredytowej, lecz z drugiej strony niższy poziom adekwatności kapitałowej w bankach zmniejsza odporność systemu finansowego na dalsze szoki i zaufanie do banków. Może to być problematyczne, gdyż nie wiadomo, czy nie nastapi kolejna fala kryzysu. Dodatkowo osłabione banki moga być postrzegane przez inwestorów jako mniej atrakcyjne i narażone na wyższe ryzyko upadłości. Z kolei zwiększenie wymogów kapitałowych w okresie recesji owszem sprzyja odporności systemu na szoki i odbudowie zaufania, lecz wzmacnia proces delewarowania i osłabia tempo odbudowy akcji kredytowej, co pogłębia i wydłuża ożywienie. Co więcej, już konieczność utrzymania w czasie recesji wymogu kapitałowego na wymaganym minimalnym poziomie regulacyjnym, przy pogarszającej się jakości portfela kredytowego, wzmacnia proces delewarowania i oddziałuje procyklicznie. Syntetyczne zestawienie tej analizy przedstawia tabela 2.

\section{Tabela 2}

Działania nadzoru makroostrożnościowego ograniczające procykliczność - korzyści i koszty

\begin{tabular}{|c|c|c|}
\hline & $\begin{array}{l}\text { Zaostrzenie wymogów } \\
\text { kapitałowych w okresie boomu }\end{array}$ & $\begin{array}{l}\text { Lagodzenie wymogów } \\
\text { kapitałowych w okresie recesji }\end{array}$ \\
\hline Korzyści & $\begin{array}{l}\text { - } \text { ograniczenie narastania ryzyka } \\
\text { systemowego } \\
\text { - } \quad \text { zmniejszenie wahań cyklu finanso- } \\
\quad \text { wego } \\
\text { - } \quad \text { wyższa odporność na szoki }\end{array}$ & $\begin{array}{l}\text { - } \text { ograniczenie procesu delewarowa- } \\
\text { nia } \\
\text { - } \\
\text { sprzyjanie ożywieniu akcji kredy- } \\
\text { towej }\end{array}$ \\
\hline Koszty & $\begin{array}{l}\text { - } \text { spadek zysków instytucji finanso- } \\
\text { wych } \\
\text { - } \\
\text { ograniczenie dostępu do usług na } \\
\text { rynku finansowym } \\
\text { - } \\
\text { ryzyko ograniczenia przyczyniania } \\
\text { się przez system finansowy do wzro- } \\
\text { stu gospodarczego }\end{array}$ & $\begin{array}{l}\text { - } \text { spadek zaufania do systemu finan- } \\
\text { sowego } \\
\text { - } \text { niższy poziom bazy kapitałowej- } \\
\text { niższa odporność na szoki }\end{array}$ \\
\hline
\end{tabular}

Źródło: opracowanie własne. 
Dodatkowo dylematy te potęgowane sa przez konflikt pomiędzy instytucjami wchodzacymi w skład organu odpowiedzialnego za nadzór makroostrożnościowy, konflikt między spojrzeniem z perspektywy mikro- i makroostrożnościowej oraz przez cykl wyborczy. Jeśli jest to gremium kolektywne, w którym uczestniczą przedstawiciele rządu (np. ministerstwa finansów), banku centralnego, nadzorcy mikroostrożnościowego, to ich postawa wobec podejmowania działań antycyklicznych może być odmienna w danej fazie cyklu finansowego. Zależnie od tego, która z instytucji odgrywa czołową rolę (bądź ma efektywne prawo weta), decyzje podjęte przez gremium jako całość mogą być różne ${ }^{9}$, co ilustruje tabela 3. Wynika z niej, że jeśli dominującą rolę w instytucji nadzoru makroostrożnościowego odgrywa rząd, polityka makroostrożnościowa może nie być w wystarczającym stopniu antycykliczna, co ograniczałoby jej skuteczność. Stanowi to kolejny argument za powierzeniem jej niezależnemu bankowi centralnemu.

\section{Tabela 3}

Potencjalne nastawienie poszczególnych instytucji wobec polityki makroostrożnościowej zależnie od fazy cyklu finansowego

\begin{tabular}{|l|l|l|}
\cline { 2 - 3 } \multicolumn{1}{c|}{} & \multicolumn{1}{c|}{$\begin{array}{c}\text { Ożywienie w cyklu } \\
\text { finansowym }\end{array}$} & \multicolumn{1}{c|}{$\begin{array}{c}\text { Depresja w cyklu } \\
\text { finansowym }\end{array}$} \\
\hline Bank centralny & antycykliczne & antycykliczne \\
\hline Rząd & $\begin{array}{l}\text { tendencja do unikania } \\
\text { postawy antycyklicznej }\end{array}$ & antycykliczne \\
\hline Nadzorca mikroostrożnościowy & $\begin{array}{l}\text { tendencja do unikania } \\
\text { postawy antycyklicznej }\end{array}$ & $\begin{array}{l}\text { tendencja do postawy } \\
\text { procyklicznej }\end{array}$ \\
\hline
\end{tabular}

Źródło: opracowanie własne.

Te dylematy mogą utrudnić nadzorowi makroostrożnościowemu działania antycykliczne i skłaniać do niepodejmowania działań w każdej $\mathrm{z}$ faz cyklu - tzw. paradoks bezczynności (ang. inaction bias). W okresie boomu mogłoby to wynikać z nacisków politycznych i lobby sektora bankowego, protestującego przeciwko ograniczaniu przychodów z akcji kredy-

${ }^{9}$ Bank centralny najprawdopodobniej w każdej fazie cyklu przyjmie postawę antycykliczna, tj. będzie identyfikował i analizował ryzyko systemowe oraz dążył do ograniczania procykliczności zgodnie z celem dbania o stabilność finansową. Rząd może w okresie ożywienia niechętnie zaostrzać politykę makroostrożnościowa, gdyż będzie to ograniczało tempo poprawy kondycji instytucji finansowych, a zatem akcję kredytową i rozwój gospodarczy, co mogły skutkować niższymi wpływami do budżetu. W okresie recesji będzie najprawdopodobniej sprzyjał łagodzeniu polityki makroostrożnościowej, gdyż zajdzie odwrotna zależność i saldo budżetowe prawdopodobnie wtedy ulegnie poprawie. Nadzorca mikroostrożnościowy w okresie ożywienia, gdy wyniki poszczególnych instytucji finansowych poprawiają się, może nie być skłonny dążyć do zastosowania narzędzi ograniczających tempo poprawy kondycji nadzorowanych instytucji. Z kolei w okresie recesji, może sprzyjać wzrostowi ich wyposażenia kapitałowego w celu zwiększenia ich bezpieczeństwa, co jednak z perspektywy makroostrożnościowej potencjalnie zadziałałoby procyklicznie. 
towej, i podkreślaniu, że spadek rentowności sektora bankowego nie sprzyja stabilności jego kondycji. W okresie recesji zmniejszanie wymogów kapitałowych (np. przez obniżanie buforów) ograniczałoby zaufanie do sektora bankowego, co również mogłoby zmniejszać motywację do działania organu makroostrożnościowego. Paradoks bezczynności wynika również z tego, że z jednej strony koszty działań nadzoru makroostrożnościowego są pewne, mierzalne i ponoszone od razu, a z drugiej - korzyści (np. wzmocnienie odporności systemu finansowego i ograniczenie częstotliwości występowania kryzysów) sa niepewne, trudno obserwowalne i mierzalne oraz widoczne dopiero w dłuższej perspektywie. Z tego również wynika, że organ makroostrożnościowy, by móc skutecznie ograniczać procykliczność, powinien cechować się dużym zakresem niezależności. Przeciwdziałanie paradoksowi należy uznać za jedno z najważniejszych wyzwań stojących przez nadzorem makroostrożnościowym.

Nadzór makroostrożnościowy powinien również uwzględnić możliwość wypełnienia norm regulacyjnych (makroostrożnościowych) przez podmioty nimi objęte w różny sposób. Procykliczność w okresie recesji sprzyja procesowi delewarowania. Można to prześledzić na przykładzie kształtowania się współczynnika wypłacalności (ang. capital adequacy ratio - CAR) lub dodatkowego bufora kapitałowego. Po negatywnym szoku dotykajacym aktywa, aby utrzymać dany poziom adekwatności kapitałowej (CAR), banki moga (w przypadku rosnacych aktywów ważonych ryzykiem) zasadniczo postapić dwojako: tzn. zwiększyć poziom kapitału (licznik CAR) lub zmniejszyć (sprzedać) posiadane aktywa i jednocześnie „zoptymalizować” wagi ryzyka, co ma służyć obniżaniu aktywów ważonych ryzykiem (mianownik CAR). Naturalnie możliwe jest również zastosowanie obu strategii jednocześnie, jednakże skutki dla stabilności systemu finansowego zależnie od dominacji którejś z nich mogą być zgoła odmienne.

W pierwszym przypadku koszt pozyskania kapitału jest relatywnie wyższy w okresie recesji (ze względu na awersję do ryzyka), co zwiększa koszty finansowania banków. Jednak pozyskanie kapitału powoduje, że wzrasta ich baza kapitałowa oraz potencjalnie większa jest odporność na szoki, co sprzyja stabilności finansowej oraz możliwościom prowadzenia (ożywienia) akcji kredytowej. Ze względu na wysokie koszty tego rozwiązania banki moga nie być skłonne zwiększać poziom kapitału w okresie recesji i zamiast tego moga zmniejszać akcję kredytową (wybrać drugie rozwiązanie). W drugim przypadku kolektywne działania banków mogą wywołać paniczną wyprzedaż aktywów na rynku, gwałtowny spadek ich cen i obniżenie wartości, a przez efekt majątkowy negatywnie oddziaływać na kondycję zarówno innych banków, jak i sektora niefinansowego - osłabiać ich odporność na szoki, negatywnie wpływać na stabilność finansową i jeszcze bardziej sprzyjać ograniczaniu akcji kredytowej. Wyprzedaż bardziej ryzykownych aktywów przez bank ma na celu obniżenie aktywów ważonych ryzykiem, aby przy (ceteris paribus) niezmienionym poziomie kapitału utrzymać CAR na tym samym poziomie. Jednak gdy większość banków robi to jednocześnie, tworzy się negatywny efekt zewnętrzny i następuje załamanie rynku. Napędza to spiralę spadających cen aktywów i pogarszającej się jakości bazy kapitałowej banków w skali całego systemu. 
Oba warianty zestawiono w tabeli 4, z której wynika, że zasadne jest, aby nadzorca makroostrożnościowy skłaniał banki i stwarzał im warunki do wybierania pierwszej możliwości (pozyskiwanie kapitału), co jednak nie powinno odbywać się tylko przez sztywne podnoszenie wymaganego poziomu CAR w okresie recesji.

Tabela 4

Pozyskanie kapitału a delewarowanie - porównanie

\begin{tabular}{|c|c|c|}
\hline $\begin{array}{l}\text { Wplyw na } \\
\text { stabilność }\end{array}$ & Pozyskanie kapitału & Delewarowanie \\
\hline Pozytywny & $\begin{array}{l}\text { - } \text { wzrost bazy kapitałowej i odpor- } \\
\text { ności na szoki } \\
\text { - } \\
\text { możliwość odbudowy akcji kredy- } \\
\text { towej (wpływ antycykliczny) }\end{array}$ & $\begin{array}{l}\text { - spadek wielkości systemu ban- } \\
\text { kowego (i/lub poszczególnych } \\
\text { banków) }\end{array}$ \\
\hline Negatywny & $\begin{array}{l}\text { - obniżenie bieżaccej rentowności } \\
\text { (wyższy koszt pozyskania kapi- } \\
\text { tału) } \\
\text { - } \\
\text { potencjalnie wzrost wielkości } \\
\text { systemu bankowego, w tym rozwój } \\
\text { SIFI }\end{array}$ & $\begin{aligned} \text { - } & \text { ryzyko efektu panicznej wyprze- } \\
& \text { daży } \\
\text { - } & \text { zmniejszenie odporności na szoki } \\
- & \text { ograniczanie akcji kredytowej } \\
& \text { (wpływ procykliczny) }\end{aligned}$ \\
\hline
\end{tabular}

Źródło: opracowanie własne.

Jak wyżej argumentowano, niezbędne jest wykorzystywanie przez nadzór makroostrożnościowy narzędzi o antycyklicznym oddziaływaniu. H. Ren ${ }^{10}$ wskazuje na dylemat związany z ich użyciem w oparciu o z góry przyjęte zasady wobec pełnej dyskrecjonalności organu nadzoru. Opieranie się na regułach sprawia, że użycie narzędzi jest dokonywane w sposób przejrzysty i wiarygodny oraz przewidywalny, w mniejszym stopniu zaburzajacy funkcjonowanie systemu finansowego. Minimalizuje to również wpływ czynników politycznych na organ nadzoru makroostrożnościowego stosujacy antycykliczne narzędzia. Ten argument można uznać za kluczowy, gdyż warunkiem skuteczności „niepopularnych”, antycyklicznych działań nadzoru makroostrożnościowego w okresie boomu jest właśnie wspominana niezależność i umiejętność oparcia się presji politycznej i lobby sektora finansowego. Z drugiej strony nie można być więźniem przyjętych reguł i należy elastycznie reagować na zmieniajacca się i ewoluujaccą dynamikę cykli finansowych oraz zmiany strukturalne w systemie finansowym, co wymusza pozostawienie pewnej dozy dyskrecjonalności w działaniach nadzoru makroostrożnościowego.

Zdaniem C. Boria ${ }^{11}$ oparcie antycyklicznych rozwiązań na mechanizmie automatycznych stabilizatorów (w przeciwieństwie do dyskrecjonalnych dzia-

${ }^{10}$ H. Ren, Countercyclical Financial Regulation, Policy Research Working Paper 5823, The World Bank 2011, s. 5.

${ }^{11}$ Por. C. Borio, Implementing the Macroprudential Approach to Fnancial Regulation and Supervision, w: The Future of Fnancial Regulation, Financial Stability Review No. 13, Banque de France 2009, s. 37-38. 
łań nadzorców) pozwoli zmniejszyć ryzyko inaction bias i wpływu nacisków zewnętrznych na działania nadzorów, szczególnie w przypadku zacieśnienia norm regulacyjnych w okresie boomu. Działanie na zasadzie automatycznych stabilizatorów powinno być okresowo weryfikowane i uzupełnione o dyskrecjonalne decyzje, które w lepszym stopniu moga być dopasowane do zmieniającej się natury ryzyka systemowego i bieżących zagrożeń stabilności finansowej. Dodatkowo P. J. Szpunar i W. Koziński ${ }^{12}$ podkreślaja, że nie można jednoznacznie przesądzić, czy uda się zapobiec kolejnym boomom kredytowym w przyszłości, co wynika m.in. z:

- trudności w identyfikacji boomu kredytowego,

- oporu wynikającego z cyklu politycznego wobec ograniczania ekspansji kredytu,

- trudności w oszacowaniu ex ante kosztów i korzyści z działań ograniczajacych wzrost kredytu w gospodarce,

- braku bodźców do podejmowania kosztownych działań (ich sukces brak kryzysu - może być postrzegany paradoksalnie jako niepotrzebnie poniesione koszty),

- zbyt późne podjęcie działań może być nieskuteczne ze względu na możliwy arbitraż regulacyjny.

Najefektywniejsze jest więc powierzenie funkcji nadzoru makroostrożnościowemu niezależnemu bankowi centralnemu oraz przyjęcie (i upublicznienie) założeń ramowych wykorzystywania instrumentów makroostrożnościowych, ale także pozostawienie bankom marginesu dla dyskrecjonalnego działania, zależnie od aktualnych uwarunkowań rynkowych.

\section{CHARAKTER NARZĘDZI DO OGRANICZANIA PROCYKLICZNOŚCI}

Narzędzia nadzoru makroostrożnościowego, które mogą sprzyjać ograniczaniu zjawiska procykliczności i różnych rodzajów ryzyka z nim związanego, to w przypadku ${ }^{13}$ :

- nadmiernej dźwigni: stały wyższy wymóg kapitałowy (np. bufor zabezpieczający w ramach Bazylei III), bufor antycykliczny ${ }^{14}$, system dynamicznego naliczania rezerw ${ }^{15}$,

${ }^{12}$ Por. P. J. Szpunar, W. Koziński, Czy stabilność finansowa wystarcza?, w: A. Alińska (red.), Eseje o stabilności finansowej, CeDeWu, Warszawa 2012, s. 359.

${ }^{13}$ Por. IMF, Central Banking Lessons from the Crisis, Prepared by the Monetary and Capital Markets Department, 27 May 2010, s. 14-15.

${ }^{14}$ Bufory antycykliczne teoretycznie są skuteczne, ponieważ działają z dwóch stron, tj. ograniczają zarówno przyczynę, jak i skutek procykliczności. Z jednej zmniejszają procykliczność polityki kredytowej banków, a z drugiej budują bufor pozwalający na wzrost odporności na szoki (i łagodzący ich wpływ) związane z skutkami procykliczności.

${ }_{15}$ Rozwiazaniem byłoby również wprowadzenie dynamicznego systemu naliczania rezerw przy obliczeniu rezerw celowych lub zwiększenie rezerw na ryzyko ogólne dla całego portfela, co działałoby podobnie jak bufor zabezpieczający. Mechanizm dynamicznego naliczania rezerw 
- nadmiernego wzrostu ryzyka płynności: ilościowe limity ograniczające finansowanie z rynku hurtowego, ograniczenie wzrostu niedopasowania terminów,

- ograniczenia polityki zabezpieczeń: ustalenie minimalnych poziomów dyskonta, ograniczenia LTV.

Jednak niezależnie od charakteru narzędzia, największym wyzwaniem będzie opracowania mechanizmu odpowiedniej kalibracji parametrów poszczególnych narzędzi tak, by z jednej strony skutecznie przyczyniały się do ograniczania procykliczności, a z drugiej - minimalizować ich skutki uboczne (np. wzrost kosztów instytucji finansowych nimi objętych). Niezbędne jest również zbadanie kanałów transmisji poszczególnych narzędzi i ich interakcji z kanałami transmisji innej polityki (np. monetarnej). Z analizy natury czynników procykliczności oraz z trudności w ocenie, w jakim momencie cyklu finansowego znajduje się aktualnie system finansowy, wynika, że organ nadzoru makroostrożnościowego powinien z dużą ostrożnością kalibrować parametry tych narzędzi oraz wybierać moment ich zastosowania. Powinny one móc być zaostrzane i łagodzone stopniowo, zależnie od dalszego przebiegu cyklu i należy unikać gwałtownych działań oraz uwzględnić fakt, że mogą one przynieść pożądane efekty z opóźnieniem.

Jako że cykle finansowe nie są zsynchronizowane w wysokim stopniu między krajami UE, a w znacznej mierze mają charakter narodowy, implikuje to pozostawienie dużej dozy elastyczności i swobody w kształtowaniu (przynajmniej kalibrowaniu) polityki makroostrożnościowej przez władze na poziomie krajowym. Różnice w cyklach przekładają się na zróżnicowane typy ryzyka systemowego i stopień jego nasilenia, co przemawia za krajową kalibracją narzędzi ${ }^{16}$ mających im przeciwdziałać. Nie ma więc rozwiązań uniwersalnych i polityka makroostrożnościowa powinna być dostosowana każdorazowo do fazy cyklu finansowego danego kraju.

Furtką do zastosowania odpowiednio skalibrowanych narzędzi makroostrożnościowych, których ramy operacyjne sa dopiero projektowane, jest już teraz wykorzystywanie przez nadzorców mikroostrożnościowych swobody w ramach Filaru II i podejmowanie (wobec danych podmiotów) działań zmierzających do poprawy zasad zarządzania ryzykiem i sposobu obliczania oraz wysokości poziomu adekwatności kapitałowej. W świetle niedoskonałości systemu regulacji nadzorcy w ramach Filaru II moga przeciwdziałać procykliczności przez m.in. wymaganie wyższych poziomów adekwatności kapitałowej, wprowadzenie wymogu częstszego przeprowadzania stress-testów. Jednak tego typu działania mogą sprawiać, że banki w większym stopniu będą polegać na polityce nadzorczej, co może uśpić ich wewnętrzne systemy oceny ryzyka, to z kolei od nadzorców wymaga postawy proaktywnej i braku pobłażliwości

\footnotetext{
pozwoliłby na wygładzenie tempa akcji kredytowej i jednocześnie tworzenie buforów kapitałowych, które można by wykorzystać w okresie recesji. Przegląd doświadczeń z ich wykorzystania w: S. F. de Lis, A. Garcia-Herrero, Dynamic Provisioning: Some Lessons from Existing Experiences, ADBI Working Paper Series No. 218, Asian Development Bank Institute 2010, s. 5-26.

${ }^{16} \mathrm{Z}$ drugiej strony, można podnieść argument, że zaburza to spójność funkcjonowania jednolitego rynku i wprowadza nierówne warunki prowadzenie działalności bankowej w UE.
} 
(ang. regulatory forbearance), co nie zawsze miało miejsce w okresie ostatniego kryzysu.

Analiza na potrzeby nadzoru makroostrożnościowego uwzględnia fakt, że system finansowy pozostaje w ścisłym związku ze sferą realną. Z jednej strony system finansowy pełni ważne funkcje w gospodarce, z drugiej - sam pozostaje pod wpływem czynników, których źródłem jest otaczająca gospodarka. Dlatego kluczowym elementem analizy makroostrożnościowej jest identyfikacja interakcji pomiędzy poszczególnymi elementami systemu finansowego oraz kanałów wzajemnego oddziaływania pomiędzy gospodarką realną a systemem finansowym ${ }^{17}$ (jednym $\mathrm{z}$ takich kanałów jest właśnie procykliczność). Pojawia się jednak pytanie, czy polityka makroostrożnościowa powinna ograniczać procykliczność jedynie wewnątrz systemu finansowego, czy może szerzej również w sferze realnej.

A. Sławiński ${ }^{18}$ podkreśla, że możliwe jest alternatywne podejście do polityki makroostrożnościowej. Pierwsze, którego celem jest ochrona systemu bankowego przed ryzykiem systemowym przez zapobieganie kryzysom bankowym, sprzyjałoby stabilności całej gospodarki, lecz tylko o tyle, o ile zmniejsza to amplitudę wahań cykli kredytowych. Zakłada ono pasywne wykorzystanie instrumentów nadzorczych dopiero pod wpływem pojawiających się oznak narastania ryzyka systemowego. Drugie z kolei zakłada szerszą rolę polityki makroostrożnościowej - stanie się ona elementem stabilizowania koniunktury (wraz z polityka pieniężna), a nie tylko zapobiegania ryzyku systemowemu. Warunkowałoby to podejście aktywne polityki makroostrożnościowej i zmiany jej parametrów zależnie od fazy cyklu. W tym podejściu polityka ta sprzyjałaby utrzymywaniu gospodarki na ścieżce zrównoważonego wzrostu. Prezentowane przez A. Sławińskiego ujęcia można postrzegać jako etapy ewolucji roli nadzoru makroostrożnościowego. Jednak ze względu na wczesna fazę rozwoju zarówno na poziomie teoretycznym, jak i praktycznym tego typu nadzoru zasadne jest na obecnym etapie przyjęcie pierwszego podejścia, a dopiero w miarę nabywania doświadczenia w skutecznym prowadzeniu nadzoru makroostrożnościowego „obarczać” go dodatkowymi zadaniami, poza jedynie zapobieganie ryzyku systemowemu i procykliczności.

Jednocześnie istotny argument podnosi M. Marcinkowska, wskazując że antycykliczne regulacje powodujace m.in. zmiany w zasadach rachunkowości i sposobie obliczania wymogu kapitałowego, nakierowane na ograniczanie procykliczności, mogą mieć również skutki uboczne. Stwarzają one bowiem ryzyko zaciemniania obrazu aktualnej sytuacji finansowej banku i przyszłego zapotrzebowania na kapitał. Wygładzenie wyników finansowych w czasie jest bowiem zabiegiem zniekształcajaccym faktycznie generowaną rentowność w poszczególnych okresach. Może to sprzyjać manipulacji wynikiem finansowym, a nadmierne skomplikowanie regulacji może zwiększyć ryzyko obniżenia wiarygodności sprawozdań finansowych ${ }^{19}$

17 Por. O. Szczepańska, Stabilność finansowa jako cel banku centralnego, Scholar, Warszawa 2008 , s. 167.

18 Por. A. Sławiński, Kierunki ewolucji nadzoru bankowego, w: A. Alińska (red.), Polityka monetarna i fiskalna a stabilność sektora finansowego, CeDeWu, Warszawa 2012, s. 128-129.

19 Por. M. Marcinkowska, Procykliczność i antycykliczność regulacji bankowych, w: A. Janc (red.), Bankowość a kryzys na rynkach finansowych, Zeszyty Naukowe 140, Wydawnictwo Uniwersytetu Ekonomicznego w Poznaniu, Poznań 2010, s. 501. 
Analiza zjawiska procykliczności, jego istoty i czynników prowadzi do następujących wniosków w formie postulatów skutecznego jej ograniczania ${ }^{20}$ :

- propagowanie lepszego zrozumienia ryzyka: publikowanie ocen ryzyka systemowego przez nadzorców i przeglądu zasad zarządzania ryzykiem w instytucjach finansowych;

- konstruowanie reguł i praktyk nadzorczych, które w sposób bezpośrednio niezależny od fazy cyklu promowałyby bardziej precyzyjny pomiar wymiaru czasowego ryzyka i wzmocniłby odporność systemu finansowego (np. przyjęcie dłuższego horyzontu w modelowaniu ryzyka, system dynamicznego naliczania rezerw);

- wykorzystanie instrumentów nadzorczych explicite w sposób antycykliczny, aby ograniczyć narastanie nierównowag makrofinansowych i budować bufory kapitałowe;

- antycykliczne wykorzystanie polityki pieniężnej (by ograniczyć rozwój nierównowag makrofinansowych) i ostrożnościowej;

- ściślejsza współpraca między organami publicznymi na rzecz stabilności finansowej, ze względu na zróżnicowane funkcje i narzędzia w dyspozycji poszczególnych organów (elementów sieci bezpieczeństwa finansowego), aby unikać przerzucania odpowiedzialności i jednoznacznie alokować narzędzia.

Ze względu na ścisłe powiązania między cyklem finansowym i gospodarczym należy też mieć świadomość, że antycykliczne działania samego nadzoru makroostrożnościowego nie wystarczą - potrzeba skoordynowanych działań również polityki mikroostrożnościowej, fiskalnej i pieniężnej.

\section{PODSUMOWANIE}

Zdaniem nadzoru makroostrożnościowego jest identyfikacja i ograniczanie czynników procyklicznych. Ważnie jest również wprowadzanie nowych regulacji antycyklicznych. Skutki procykliczności można ograniczyć przez zwiększenie odporności systemu finansowego na szoki (np. wyższy poziom i jakość kapitału), co jednak nie ogranicza jej źródeł - do tego potrzebne jest zastosowanie narzędzi antycyklicznych, np. bufora antycyklicznego, który działałby jak automatyczny stabilizator procyklicznej polityki kredytowej banków. Działania nadzoru makroostrożnościowego powinny przyjąć postawę nie pasywna, lecz proaktywna, na bieżąco dostosowującą parametry narzędzi ostrożnościowych do danej fazy cyklu. Skuteczne ograniczanie procykliczności w systemie finansowym może oddziaływać w kierunku zmniejszenia wahań koniunkturalnych w sferze realnej.

20 Por. C. Borio et al., Procyclicality of the Financial System and Financial Stability: Issues and Policy Options, w: Marrying the Macro- and Microprudential Dimensions of Financial Stability, BIS Papers No 1, BIS 2001, s. 2 oraz W. R White, Procyclicality in the Financial System: Do We Need a New Macrofinancial Stabilisation Framework?, BIS Working Papers No 193, BIS 2006, s. 14-17. 
Mnogość źródeł czynników procyklicznych implikuje konieczność stosowania wielu narzędzi antycyklicznych, które by je ograniczały. Trudno spodziewać się, że jedno narzędzie skutecznie ograniczy zjawisko procykliczności, zasadne jest więc jednoczesne wprowadzanie kompleksowych zmian odnoszących się do wielu źródeł procykliczności. Należy również pokornie oceniać skuteczność implementowanych narzędzi makroostrożnościowych i pamiętać, że są w stanie ograniczać zazwyczaj tylko jeden czynnik. W literaturze wydaje się rysować konsensus, że potencjalnie najskuteczniejsze może być wprowadzenie antycyklicznych regulacji kapitałowych, lecz jako środków uzupełniajacych, a nie zastępujacych dotychczasowe wymogi kapitałowe.

Zasadnym pierwszym krokiem jest modyfikowanie dotychczasowych rozwiązań regulacyjnych, zmniejszajacych ich procykliczne oddziaływanie, a w następnym kroku wprowadzanie nowych narzędzi. W przypadku narzędzi antycyklicznych warunkiem sukcesu jest umiejętność opracowania przez nadzorcę systemu pozwalajacego efektywnie i w odpowiednim momencie zacieśniać oraz łagodzić parametry danego narzędzia.

By skutecznie ograniczać procykliczność, zasadne jest przyjęcie dłuższego horyzontu analizy uwzględniającego przyszłą niestabilność, tj. akumulowanie czynników strukturalnych sprzyjajacych materializacji ryzyka systemowego w przyszłości. Ważnie jest nieuleganie paradoksowi niestabilności, gdyż w okresie boomu pozornie można oceniać system jako stabilny, co wiąże się z ograniczonym użyciem zmiennych z rynków finansowych do oceny stabilności finansowej. Z charakteru procykliczności wynika, że nadzór makroostrożnościowy powinien działać zarówno w okresie ożywienia, jak i dekoniunktury. W okresie ożywienia powinien dążyć odpowiednio do ograniczenia narastania ryzyka systemowego, przez stosowanie polityki antycyklicznej, a w okresie recesji - do obniżania wymaganych norm ostrożnościowych w sposób zrównoważony. Jednak niezależnie od fazy cyklu powinien dążyć do wzmacniania odporności systemu finansowego na szoki.

Nadzorca makroostrożnościowy staje przed dylematem zarówno w okresie ożywienia, jak i recesji. Po pierwsze, zaostrzanie polityki w okresie ożywienia może być postrzegane, jako niepopularne działanie, ograniczajace rentowność sektora finansowego i pogarszające jego kondycję. W okresie recesji zarówno zwiększanie wymogu kapitałowego, jak i jego zmniejszanie moga prowadzić do niestabilności finansowej (odpowiednio - pogłębienie delewarowania lub spadek zaufania i odporności na szoki). Ponadto ze względu na różne nastawienie poszczególnych instytucji wchodzących w skład organu nadzoru makroostrożnościowego wobec procykliczności, decyzje i działania podjęte przez gremium jako całość, mogą być odmienne, zależnie od tego, która z instytucji odgrywa czołową rolę (bądź ma efektywne prawo weta).

$\mathrm{Z}$ analizy przeprowadzonej $\mathrm{w}$ artykule wynika, że teza postawiona na wstępie została potwierdzona i procykliczność systemu finansowego znacząco wpływa na sposób sprawowania nadzoru makroostrożnościowego. Można zaproponować praktyczne rekomendacje:

1. Organ makroostrożnościowy, by móc skutecznie ograniczać procykliczność, powinien cechować się dużym zakresem niezależności oraz przyjąć 
postawę proaktywną (przeciwdziałać inaction bias), co stanowi argument o powierzeniu tego obowiązku bankowi centralnemu.

2. Nadzór makroostrożnościowy powinien również uwzględnić możliwość wypełnienia w różny sposób norm makroostrożnościowych przez podmioty nimi objęte, co może mieć odmienne skutki dla stabilności finansowej.

3. Nadzór makroostrożnościowy powinien przyjąć i upublicznić założenia ramowe wykorzystywania instrumentów, ale pozostawiać sobie margines dyskrecjonalnego działania.

4. Polityka makroostrożnościowa powinna być skoordynowana z polityka fiskalną, pieniężną i mikroostrożnościowa. Należy unikać sytuacji, w których oddziaływałyby w przeciwnych kierunkach.

5. Potrzebne jest opracowanie sposobu operacjonalizacji, tj. praktycznego użycia poszczególnych typów narzędzi, zbadanie mechanizmów transmisji i ewentualnych skutków ubocznych, uwzględniając ich zastosowanie w obu fazach cyklu finansowego.

6. Kluczowe dla sukcesu ograniczania czynników procyklicznych jest również podejmowanie skoordynowanych działań w skali nie tylko UE, lecz także i globalnej, by zapobiec arbitrażowi regulacyjnemu.

dr Pawet Smaga

Szkoła Główna Handlowa w Warszawie

oraz Narodowy Bank Polski

pawel.smaga@nbp.pl

\section{INFLUENCE OF PROCYCLICALITY ON THE CONDUCT OF MACROPRUDENTIAL POLICY}

Summary

This article aims to analyse the implications of time dimension of systemic risk (procyclicality) on the conduct of macroprudential policy. A multitude of procyclicality factors imply the need for multiple anticyclical tools addressing particular factors. The analysis shows that macroprudential authority should take a proactive stance and analyse financial stability within a longer time horizon, so as not to experience the paradox of financial instability or be subject to inaction bias. Macroprudential supervision should act both during boom (limiting the build-up of systemic risk) and recession (mitigating its materialisation) and, regardless of the financial cycle phase, seek to strengthen resilience of the financial system to shocks. The key to its effectiveness is development of an operational framework and ways to effectively implement its tools, taking into account different attitudes towards procyclicality of the institutions responsible for conducting macroprudential policy. 
Copyright of Journal of Law, Economics and Sociology is the property of Faculty of Law and Administration of Adam Mickiewicz University in Poznan and its content may not be copied or emailed to multiple sites or posted to a listserv without the copyright holder's express written permission. However, users may print, download, or email articles for individual use.

Właścicielem praw autorskich do „Ruchu Prawniczego, Ekonomicznego i Socjologicznego” jest Wydział Prawa i Administracji Uniwersytetu im. Adama Mickiewicza w Poznaniu. Zawartość czasopisma nie może być kopiowana, przesyłana do innych stron internetowych bądź zamieszczana na blogach bez pisemnej zgody wydawcy. Niemniej artykuły można drukować, kopiować lub przesyłać w formie elektronicznej na własny użytek. 